\title{
Update on the Evaluation of the Anti-Obesity Effect of Green Tea (Camellia sinensis)
}

\author{
Halima Tarassinga Abiba Sultane ${ }^{1}\left(\mathbb{C}\right.$, Edgar Manuel Cambaza ${ }^{2,3}$ \\ ${ }^{1}$ Tertiary School of Health Sciences, Mozambican Tertiary Institute of Science and Technology (ISCTEM), Maputo, Mozambique \\ ${ }^{2}$ Laboratory of Agricultural and Food Process Engineering, Graduate School of Agriculture, Hokkaido University, Hokkaido, Japan \\ ${ }^{3}$ Department of Biological Sciences, Faculty of Sciences, Eduardo Mondlane University (UEM), Maputo, Mozambique
}

Correspondence Author: Edgar Manuel Cambaza

E-mail: accademus@protonmail.com

Received: $08.02 .2019 \quad$ Accepted: 20.08 .2019

\begin{abstract}
Objective: Obesity is a worldwide rising risk factor for numerous incommunicable illnesses. The most common interventions have been ineffective from a public health perspective. Green tea (Camellia sinensis) seems to be an effective well-known alternative but there is a need to see the most updated and reliable information on the matter. The study aimed to verify how effective is green tea as reductor of human body mass index (BMI).

Methods: This meta-analysis reviewed recent controlled randomized trials on the effect of catechin and caffeine in the BMI of adult male and female subjects. The analysis did not include studies including alternative therapies or drugs potentially affecting BMI. The studies presented the quantity of catechin and caffeine (mg). Body mass index and waist circumference were measured before and after the interventions. The trials lasted two to eight months, depending on the study designs.

Results and Conclusion: Five studies met the criteria for the current analysis. In one study, the subjects took oral capsules of green tea extract $(379 \mathrm{mg})$. Overall, daily doses of catechin varied from $208-1200 \mathrm{mg}$, and caffeine from undetectable levels to $480 \mathrm{mg}$ (the tea products were either enriched, capsules or canned with known levels). All showed reduction in body weight, the average BMI reduction was $0.68 \mathrm{~kg} / \mathrm{m} 2$, and waist circumference was $1,5 \mathrm{~cm}$. There was a direct relationship between the concentration of catechin and reduction of BMI, but the BMI appeared to drop to a certain threshold of "optimal" weight, close to values considered as normal weight by the World Health Organization (WHO). There were few cases suggesting abdominal discomfort, but there they did not require additional treatment or hospitalization. Green tea consistently showed ability to reduce weight to a less risky level for health. Yet, it is now necessary to develop dose-response models for its active compounds and clarify the dynamics of the dosage over time. Furthermore, green tea is perhaps more effective in synergy with wellknown methods to maintain or reduce weight, such as balanced diets or physical exercise.
\end{abstract}

Keywords: Green tea, obesity, catechin, caffeine, body mass index, waist circumference

\section{INTRODUCTION}

Obesity occurs when calorie intake is higher than energy expenditure, resulting in excessive lipid accumulation in the adipose tissue, and it is well-known as an increasingly prevalent medical condition (1). It is a major risk factor for several cardiovascular diseases, diabetes, pulmonary illnesses, certain types of cancer and osteoarthritis (2). In 2016, the World Health Organization (WHO) estimated that over 1.9 billion adults (> 18-year old) were overweight from which more than 650 million were obese, 39\% of men and $40 \%$ of women were overweight and $13 \%$ of the world population ( $11 \%$ of men and $15 \%$ of women) were obese (3). In 2018, Piche et al. (4) published more recent estimates as $30 \%$ of men and $35 \%$ of women obese worldwide. According to them, it has doubled in more than 70 countries since 1980.
In Mozambique, the prevalence of obesity in adults is 7,2\% (5).

Despite of several interventions to combat reduce the prevalence of obesity through promotion of healthier lifestyle, medication, surgical interventions, physical activity and low-calorie diets, results have not been satisfactory and their effects do not last for long, and sometimes patients face adverse effects of such therapies $(2,6-8)$. Thus, it is crucial to search for effective, easy to use, tolerable and economic alternatives. Recently, natural phytotherapeutic supplements are drawing attention, and green tea (from Camellia sinensis) is the most widely used (9-11).

Green tea's anti-obesity properties is associated to its relatively high content of catechins, antioxidants consisting 
of (-)-epicatechin (EC), (-)-epicatechin-3-gallate (ECG), (-)-epigallo-catechin (EGC), and (-)-epigallocatechin-3gallate (EGCG) (12). According to Kao et al. (13), EGCG was capable of reducing up to $29 \%$ of body weight of rats within one week, when injected in the peritoneum. The authors added that such effect is due to EGCG's molecular inhibition of fatty acid synthase. Catechins also inhibit a-amylase and lipase, interfere with emulsification, digestion, and fungal solubilization of lipids $(14,15)$. Akhlaghi and Kohanmoo (15) summarized the same information and added other possible mechanisms at which catechins can affect weight loss, including: (a) appetite control, perhaps by inhibiting ghrelin, (b) interaction with intestinal bacteria, resulting in its breakdown into bioavailable components with potential anti-obesity effects, and (c) increasing the population of colonic bacteria and selecting species capable of affecting converting lipids into short-chain fatty acids. Though clinical evidence supports green tea's anti-obesity effects, there are some contradictions and inconclusive findings. Furthermore, optimal intake is yet to be understood (16).

Considering the importance of obesity and the lack of effective, safe and long-lasting strategies to control it, the current study was performed on green tea, since it is inexpensive and easy to use, with minimal collateral effects. Thus, it aims to investigate how green tea affects weight loss in overweight and obese subjects.

\section{METHODS}

The study comprised a meta-review of randomized controlled clinical studies about the impact of green tea on weight loss in overweight and obese patients. The participants were healthy male and female subjects, at least 18 years old. They were overweight $\left(>25 \mathrm{~kg} / \mathrm{m}^{2}\right)$ or obese $\left(>30 \mathrm{~kg} / \mathrm{m}^{2}\right)$ according to standards by the WHO standards for BMI and waist circumference (which ideally should be within $85-95 \mathrm{~cm}$ in healthy individuals) $(17,18)$. The current analysis did not include studies in which participants used other medicines potentially affecting body weight. They used exclusively green tea or its extract. Were excluded studies in which the chemical composition of the tea was not specified or it was mixed with other ingredients.

All studies considered provided, to their control groups, a placebo or a smaller dose of great tea in relation to the experimental group. Studies where patients performed physical exercise were excluded. All experiments lasted at least two months and the studies were all performed during the last ten years.

Initially, 30 studies seemed potentially relevant. However, 11 were excluded because they were per si literature reviews. Then, 9 were excluded because they had been performed over 10 years before. Three were excluded because they used other types of intervention together with green tea, and 2 more were excluded because they did not presented measurements of both BMI and waist circumference. Finally, 5 articles matched all criteria for this study and they were analyzed (Table 1). It was also necessary to perform an analysis of covariance (ANOVA, a $=0.05$ ) in Jamovi (Version 0.9.5.13, Jamovi, Project, Amsterdam, Netherlands) (19) to determine if the weight loss in female and male subjects were significantly different and linear regression to visualize the relationship between catechin consumption and body loss. The latter analysis was not performed for waist circumference and caffeine because of some inconsistencies.

Table 1. Demographic characteristics of the subjects analyzed.

\begin{tabular}{|c|c|c|c|c|c|c|c|}
\hline Authors & $\begin{array}{l}\text { Intervention } \\
\text { and control }\end{array}$ & $\begin{array}{l}\text { Sample } \\
\text { size }\end{array}$ & $\begin{array}{l}\text { Number of randomized } \\
\text { participants }\end{array}$ & $\begin{array}{l}\text { Number of } \\
\text { participants in the end } \\
\text { of the study }\end{array}$ & $\begin{array}{l}\text { Participants in the } \\
\text { end of the study } \\
\text { (\%) }\end{array}$ & $\begin{array}{c}\text { Female/male } \\
\text { ratio }\end{array}$ & $\begin{array}{c}\text { Average age } \\
\text { (sd) }\end{array}$ \\
\hline Suliburska et al. (26) & $\begin{array}{l}\text { 11: green tea } \\
\text { C1: placebo }\end{array}$ & $\begin{array}{l}\text { I1: } 23 \\
\mathrm{C} 1: 23\end{array}$ & $\begin{array}{l}\text { I1: } 23 \\
\mathrm{C} 1: 23\end{array}$ & $\begin{array}{l}\text { I1: } 23 \\
\text { C1: } 23\end{array}$ & $\begin{array}{l}\text { I1: } 100 \% \\
\text { C1: } 100 \%\end{array}$ & $\begin{array}{l}\text { I1: } 1: 1 \\
\mathrm{C} 1: 1: 1\end{array}$ & $\begin{array}{l}\text { I1: } 49(9) \\
\text { C1: } 52(8)\end{array}$ \\
\hline Wang et al. (21) & $\begin{array}{l}\text { 12: green tea } \\
\text { C2: placebo }\end{array}$ & $\begin{array}{l}\text { I2: } 205 \\
\text { C2: } 205\end{array}$ & $\begin{array}{l}\text { I2: } 192 \\
\text { C2: } 192\end{array}$ & $\begin{array}{l}\text { I2: } 182 \\
\text { C2: } 182\end{array}$ & $\begin{array}{l}\text { 12: } 95 \% \\
\text { C2: } 95 \%\end{array}$ & $\begin{array}{l}12: 3: 1 \\
\text { C2: } 3: 1\end{array}$ & $\begin{array}{l}\text { I2: } 37(9) \\
\text { C2: } 37(9)\end{array}$ \\
\hline Brown et al. (23) & $\begin{array}{l}\text { 13: green tea } \\
\text { C3: placebo }\end{array}$ & $\begin{array}{l}13: 67 \\
\mathrm{C3}: 70\end{array}$ & $\begin{array}{l}\text { 13: } 64 \\
\text { C3: } 64\end{array}$ & $\begin{array}{l}\text { 13: } 64 \\
\text { C3: } 64\end{array}$ & $\begin{array}{l}\text { 13: } 100 \% \\
\text { C3: } 100 \%\end{array}$ & $\begin{array}{l}\text { 13: } 0: 1 \\
\text { C3: } 0: 1\end{array}$ & $\begin{array}{l}13: 50(5.5) \\
\text { C3: } 49(5.5)\end{array}$ \\
\hline Nabi et al. (20) & $\begin{array}{l}\text { 14: green tea } \\
\text { C4: placebo }\end{array}$ & $\begin{array}{l}\text { 14: } 41 \\
\text { C4: } 41\end{array}$ & $\begin{array}{l}14: 29 \\
\text { C4: } 29\end{array}$ & $\begin{array}{l}14: 29 \\
\text { C4: } 29\end{array}$ & $\begin{array}{l}\text { 14: } 100 \% \\
\text { C4: } 100 \%\end{array}$ & $\begin{array}{l}14: 2: 1 \\
\text { C4: } 2: 1\end{array}$ & $\begin{array}{c}14: 46(6.4) \\
C 4: 48(7.58)\end{array}$ \\
\hline Sone et al. (27) & $\begin{array}{l}\text { 15: green tea } \\
\text { C5: placebo }\end{array}$ & $\begin{array}{l}15: 30 \\
\text { C5: } 30\end{array}$ & $\begin{array}{l}15: 25 \\
\text { C5: } 26\end{array}$ & $\begin{array}{l}15: 25 \\
\text { C5: } 26\end{array}$ & $\begin{array}{l}\text { 15: } 100 \% \\
\text { C5: } 100 \%\end{array}$ & $\begin{array}{l}15: 2: 1 \\
\text { C5: } 2: 1\end{array}$ & $\begin{array}{l}\text { 15: } 43(14.8) \\
\text { C5: } 48(12.4)\end{array}$ \\
\hline
\end{tabular}

C: control; I: intervention; sd: standard deviation

\section{RESULTS and DISCUSSION}

All authors consulted presented reduction of the average BMI, particularly Nabi et al. (20), likely because they used higher daily levels of catechins (1200mg) and caffeine $(480 \mathrm{mg}$; see Table 2), resulting in an average IMC reduction of $3.1 \mathrm{~kg} /$ $\mathrm{m} 2$ (Table 3). The overall average BMI reduction was 0.68 $\mathrm{kg} / \mathrm{m} 2$. It is worthwhile mentioning Wang et al. (21), who divided the intervention group in three subgroups, IG1, IG2 and IG3, the order representing an increased concentration of catechin and caffeine. The subgroup IG3 did not present significant weight reduction, and the average BMI actually appeared to increase slightly. This might have been due to well-known limitations of BMI itself as a measure of BMI, as 
it for instance misrepresents the state of body fat content in several circumstances, especially because of the muscular mass (22). For instance, the same individuals showed final values of waist circumference value inversely proportional to the amount of catechin consumed daily, though waist circumference is still to be discussed in detail. In all studies, the placebo did not present considerable BMI decline. Three studies presented considerable differences between the intervention groups and the placebos, especially the study by Brown et al. (23) where intervention took longer ( 8 months) if compared to the others ( $\leq 3$ months). Thus, it seems safe to assume that consumption of green tea affected BMI. Auvichayapat et al. (9) found similar results in Thailand, Matsuyama et al. (24) in Japanese children, and Jurgens et al. (16) in another meta-analysis.

It is important to know if green tea had a similar effect in both female and male subjects, because the demographic differences between the studies might have affected the results. The ANOVA test in Table 4 does not show significant differences between the results assuming the different ratios between male and female subjects $(p=0.472)$.

Table 2. Description of the interventions used in the selected studies.

\begin{tabular}{|c|c|c|c|c|c|c|c|c|}
\hline Authors & $\begin{array}{l}\text { Intervention group } \\
\text { (s) (delivery method, } \\
\text { frequency, total doses/ } \\
\text { day) }\end{array}$ & $\begin{array}{l}\text { Catechin } \\
\text { content per } \\
\text { intervention } \\
\text { group }\end{array}$ & $\begin{array}{l}\text { Caffeine } \\
\text { content per } \\
\text { intervention } \\
\text { group }\end{array}$ & $\begin{array}{l}\text { Control group } \\
\text { (delivery method, } \\
\text { frequency, total } \\
\text { doses/day) }\end{array}$ & Duration & $\begin{array}{l}\text { Other } \\
\text { interventions } \\
\text { for weight loss }\end{array}$ & $\begin{array}{c}\text { Co- } \\
\text { medication }\end{array}$ & $\begin{array}{l}\text { Co- } \\
\text { morbidity }\end{array}$ \\
\hline $\begin{array}{l}\text { Suliburska et } \\
\text { al. (26) }\end{array}$ & $\begin{array}{l}1 \text { oral capsule (379mg) } \\
\text { of green tea extract, } \\
\text { daily (morning) }\end{array}$ & 208mg (daily) & $\begin{array}{l}\text { No caffeine } \\
\text { detected }\end{array}$ & $\begin{array}{c}1 \text { oral capsule }(379 \mathrm{mg}) \\
\text { of placebo extract, } \\
\text { daily (morning) }\end{array}$ & $\begin{array}{l}\text { I1: } 3 \text { months } \\
\text { C1: } 3 \text { months }\end{array}$ & No & No & No \\
\hline $\begin{array}{l}\text { Wang et al. } \\
\quad(21) * *\end{array}$ & $\begin{array}{c}1 \text { cup }(250 \mathrm{ml} \text { ) green tea } \\
\text { daily in } 3 \text { intervention } \\
\text { groups }\left(G l^{*}\right)\end{array}$ & $\begin{array}{l}\text { GI1 - 458mg } \\
\text { GI2-468mg } \\
\text { GI3 - 886mg }\end{array}$ & $\begin{array}{l}\text { GI1 - 104mg } \\
\text { GI2 - 126mg } \\
\text { GT3 - 198mg }\end{array}$ & $\begin{array}{c}1 \text { cup of placebo with } \\
30 \mathrm{mg} \text { of catechin and } \\
10 \mathrm{mg} \text { of caffeine }\end{array}$ & $\begin{array}{l}\text { I2: } 3 \text { months } \\
\text { C2: } 3 \text { months }\end{array}$ & No & No & No \\
\hline $\begin{array}{l}\text { Brown et al. } \\
\text { (23) }\end{array}$ & $\begin{array}{c}1 \text { oral capsule }(530 \mathrm{mg}) \\
\text { of green tea, } 2 x / \text { day }\end{array}$ & $\begin{array}{l}\text { 404mg per } \\
\text { capsule }\end{array}$ & $<1 \%$ & $\begin{array}{c}1 \text { placebo capsule } 2 x / \\
\text { day }\end{array}$ & $\begin{array}{l}\text { 13: } 8 \text { months } \\
\text { C3: } 8 \text { months }\end{array}$ & No & No & No \\
\hline $\begin{array}{l}\text { Nabi et al. } \\
(20)^{*}\end{array}$ & $\begin{array}{c}1 \text { glass }(150 \mathrm{ml}) \text { of green } \\
\text { tea } 2 x / \text { day }\end{array}$ & $1200 \mathrm{mg}$ & $480 \mathrm{mg}$ & $\begin{array}{c}1 \text { glass }(150 \mathrm{ml}) \text { of } \\
\text { placebo } 2 x / \text { day }\end{array}$ & $\begin{array}{l}\text { 14: } 3 \text { months } \\
\text { c4: } 3 \text { months }\end{array}$ & No & No & No \\
\hline $\begin{array}{l}\text { Sone et al. } \\
\text { (27) ** }\end{array}$ & $\begin{array}{c}1 \text { glass }(500 \mathrm{ml}) \text { of green } \\
\text { tea daily }\end{array}$ & $400 \mathrm{mg}$ & $105 \mathrm{mg}$ & $\begin{array}{l}1 \text { glass }(500 \mathrm{ml}) \text { of } \\
\text { placebo containing } \\
100 \mathrm{mg} \text { of catechins } \\
\text { daily }\end{array}$ & $\begin{array}{l}\text { I5: } 2 \text { months } \\
\text { C5: } 2 \text { months }\end{array}$ & No & No & No \\
\hline
\end{tabular}

GI - intervention group; * Catechin and caffeine information from the label; ** Tea with catechin and caffeine extracted, and then enriched with these compounds.

Table 3. Results of the analyzes.

\begin{tabular}{|c|c|c|c|c|c|}
\hline \multirow{2}{*}{ Authors } & \multicolumn{2}{|c|}{ BMI (kg/m2) } & \multicolumn{2}{|c|}{ Waist circumference $(\mathrm{cm})$} & \multirow{2}{*}{$\%$ of patients with adverse effects } \\
\hline & Baseline & Results after intervention & Baseline & Results after intervention & \\
\hline Suliburska et al. (26) & $\begin{array}{l}11: 32.07 \pm 2.41 \\
C 1: 33.45 \pm 2.65\end{array}$ & $\begin{array}{l}11: 31.71 \pm 2.29 \downarrow \\
\mathrm{C} 1: 33.36 \pm 2.66 \downarrow\end{array}$ & $\begin{array}{l}\text { I1: } 101.78 \pm 6.42 \\
\text { C1: } 104.98 \pm 6.53\end{array}$ & $\begin{array}{l}\text { I1: } 101.15 \pm 6.42 \downarrow \\
\text { C1: } 105.02 \pm 6.10 \uparrow\end{array}$ & No \\
\hline Wang et al. (21) & $\begin{array}{l}\mathrm{GI} 1-27.1 \pm 2 \\
\mathrm{GI} 2-27.2 \pm 3 \\
\mathrm{GI}-26.8 \pm 2 \\
\mathrm{C} 2-26.8 \pm 2\end{array}$ & $\begin{array}{l}\mathrm{GI} 1-26.8 \pm 2.0 \downarrow \\
\mathrm{GI} 2-26.8 \pm 2.4 \downarrow \\
\mathrm{GI}-26.9 \pm 2.5 \uparrow \\
\mathrm{C} 2-26.3 \pm 2.2 \downarrow\end{array}$ & $\begin{array}{l}\mathrm{G} I 1-96.1 \pm 5.8 \\
\mathrm{GI}-95.9 \pm 7.0 \\
\mathrm{GI}-95.5 \pm 6.0 \\
\mathrm{C} 2-94.5 \pm 6.0\end{array}$ & $\begin{array}{c}\mathrm{GI} 1-95.0 \pm 6.2 \downarrow \\
\mathrm{G} / 2-94.6 \pm 7.0 \downarrow \\
\mathrm{GI} 3-93.6 \pm 7.0 \downarrow \\
\mathrm{C} 2-94.3 \pm 5.8 \downarrow\end{array}$ & No \\
\hline Brown et al. (23) & $\begin{array}{l}\text { 13: } 31.7 \\
\text { C3: } 31.4\end{array}$ & $\begin{array}{l}\text { 13: } 31.5 \downarrow \\
\text { C3: } 31.6 \uparrow\end{array}$ & $\mathrm{N} / \mathrm{A}$ & N/A & $\begin{array}{l}\text { 13: } 58 \% \\
\text { C3: } 66 \%\end{array}$ \\
\hline Nabi et al. (20) & $\begin{array}{l}14: 29.95 \pm 1.79 \\
C 4: 29.69 \pm 2.01\end{array}$ & $\begin{array}{l}14: 26.86 \pm 2.59 \downarrow \\
C 4: 27.07 \pm 2.22 \downarrow\end{array}$ & $\begin{array}{l}14: 87.77 \pm 6.06 \\
C 4: 86.94 \pm 8.8\end{array}$ & $\begin{array}{l}14: 83.91 \pm 6.13 \downarrow \\
C 4: 85.23 \pm 7.8 \downarrow\end{array}$ & $\begin{array}{l}\text { Non-specified (there were few } \\
\text { cases of abdominal discomfort) }\end{array}$ \\
\hline Sone et al. (27) & $\begin{array}{l}15: 24.6 \pm 4.3 \\
C 5: 24.5 \pm 4.2\end{array}$ & $\begin{array}{l}\text { I5: } 24.0 \pm 4.1 \downarrow \\
\text { C5: } 24.1 \pm 3.9 \downarrow\end{array}$ & $\begin{array}{c}\mathrm{I} 5: 85.0 \pm 12.7 \\
\mathrm{C} 5: 85.7 \pm 4.2\end{array}$ & $\begin{array}{l}15: 82.7 \pm 12.2 \downarrow \\
\mathrm{C} 5: 83.9 \pm 11.4 \downarrow\end{array}$ & ( \\
\hline
\end{tabular}

N/A: Not applicable

Table 4. ANOVA of average BMI reduction between the groups with distinct ratios female/male

\begin{tabular}{|c|c|c|c|c|c|}
\hline & Sum of Squares & $d f$ & Mean Square & $F$ & $p$ \\
\hline Ratio female/male & 3.57 & 3 & 1.19 & 1.09 & 0.472 \\
\hline Residuals & 3.27 & 3 & 1.09 & & \\
\hline
\end{tabular}

$d f$ : degrees of freedom 
Figure 1 shows a direct relationship between daily catechin intake and reduction of BMI (Pearson's coefficient = 0.67). However, it is important to bear in mind that these interventions had different duration and that might have impacted the final outcome. Yet, since the Pearson's coefficient shows an acceptable correlation between the daily intake and BMI loss, it is possible that green tea induces weight loss to a certain threshold at which BMI maintains steady. Brown et al. (23) conducted their study through eight months but there is no information on the gradual weight loss during this period and it makes difficult to know if such threshold exists through their observations. Since the impact of green tea on BMI has already been demonstrated, further analysis should be longitudinal to clarify the dynamics of weight loss over time.

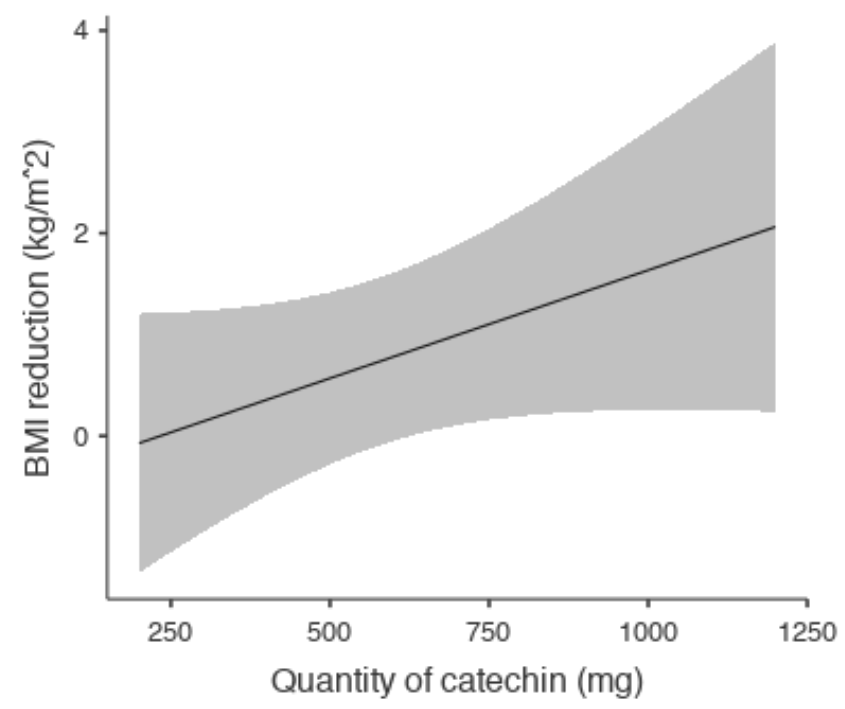

Figure 1. Relationship between daily intake of catechin and BMI loss. The shade represents $95 \%$ confidence interval. The negative values of the vertical axis represent weight gain.

Results were not considerably different regarding waist circumference. Nabi et al. (20) again indicated the most pronounced reduction $(3.86 \mathrm{~cm})$, certainly because the patients received higher daily doses of catechins and caffeine. The average reduction for all studies (in which it was measured) was $1,5 \mathrm{~cm}$. Wang et al. (21) did not find increased concentration of green tea to be directly proportional to reduction of waist circumference, but, the final outcome (the final size) was proportional to the concentration. It sustains the previous conclusion that there is a threshold at which green tea exerts its weight reducing effects, depending on particular variables still to be considered (possibly genetic, physiological or morphological, lifestyle, environmental, etc.). It is equally important to observe that most subjects Wang et al. (21) studied were not obese but rather overweight, and considering the standard deviations, very few were likely obese in comparison to the entire sample. Thus, perhaps tea only reduced the body fat into an "optimal" range. There is no agreement about such value, as it depends on several factors, but WHO Expert Consultation (18) showed that risk for cardiovascular disease increases considerably when the circumference is within the range $85-95 \mathrm{~cm}$. Thus, the results show that the mixture of catechins and caffeine in green tea is beneficial for the reduction of waist circumference. Hursel et al. (25) made similar observations through another metaanalysis and this reinforces the idea of green tea as regulator of human BMI.

Regarding adverse effects, Brown et al. (23) and Nabi et al. (20) reported few cases in which patients reported slight abdominal discomfort. However, such effects did not require hospitalization or any special treatment. Furthermore, there is no evidence indicating that green was the sole cause, or the cause at all, of the adverse effects.

\section{CONCLUSION}

The current study suggests that green tea can be a reliable alternative to treating overweight or obese patients, since it was effective, well-tolerated, with no significant adverse effects. However, there is a need to expand the study, explore it for longer periods and longitudinally, to find out how green tea extract functions over time and determine the doses or adequate posology for the treatment of obesity. The method can be coupled with other treatments such as diets and physical exercise. Larger samples might further improve the results.

Ackowledgement: Authors would like to thank Dr. Ilidio Manjate and Dr. Vangwaia Romeieque.

\section{REFERENCES}

[1] Caballero B. The global epidemic of obesity: an overview. Epidemiologic reviews. 2007;29:1-5.

[2] Rodgers RJ, Tschop MH, Wilding JP. Anti-obesity drugs: past, present and future. Dis Model Mech. 2012;5(5):621-626.

[3] World Health Organization. Obesity and overweight: World Health Organization; 2018 [updated 16 February 2018. Available from: https://www.who.int/news-room/fact-sheets/ detail/obesity-and-overweight.

[4] Piche ME, Poirier P, Lemieux I, Despres JP. Overview of Epidemiology and Contribution of Obesity and Body Fat Distribution to Cardiovascular Disease: An Update. Prog Cardiovasc Dis. 2018;61(2):103-113.

[5] Central Inteligence Agency. Field listing: obesity - adult prevalence rate Washington, D.C., U. S.: Central Inteligence Agency; 2016 [Available from: https://www.cia.gov/library/ publications/the-world-factbook/fields/367.html.

[6] Diepvens K, Westerterp KR, Westerterp-Plantenga MS. Obesity and thermogenesis related to the consumption of caffeine, ephedrine, capsaicin, and green tea. Am J Physiol Regul Integr Comp Physiol. 2007;292(1):R77-85.

[7] Paul-Ebhohimhen V, Avenell A. A systematic review of the effectiveness of group versus individual treatments for adult obesity. Obes Facts. 2009;2(1):17-24.

[8] Leblanc ES, O'Connor E, Whitlock EP, Patnode CD, Kapka T. Effectiveness of primary care-relevant treatments for obesity 
in adults: a systematic evidence review for the U.S. Preventive Services Task Force. Ann Intern Med. 2011;155(7):434-447.

[9] Auvichayapat P, Prapochanung M, Tunkamnerdthai O, Sripanidkulchai BO, Auvichayapat N, Thinkhamrop B, Kunhasura S, Wongpratoom S, Sinawat S, Hongprapas P. Effectiveness of green tea on weight reduction in obese Thais: a randomized, controlled trial. Physiol Behav. 2008;93(3):486491.

[10] Dostal AM, Samavat H, Espejo L, Arikawa AY, StendellHollis NR, Kurzer MS. Green tea extract and catechol-omethyltransferase genotype modify fasting serum insulin and plasma adiponectin concentrations in a randomized controlled trial of overweight and obese postmenopausal women. J Nutr. 2016;146(1):38-45.

[11] Kumar NB, Patel R, Pow-Sang J, Spiess PE, Salup R, Williams CR, Schell MJ. Long-term supplementation of decaffeinated green tea extract does not modify body weight or abdominal obesity in a randomized trial of men at high risk for prostate cancer. Oncotarget. 2017;8(58):99093.

[12] Lin JK, Lin-Shiau SY. Mechanisms of hypolipidemic and antiobesity effects of tea and tea polyphenols. Mol Nutr Food Res. 2006;50(2):211-217.

[13] Kao YH, Hiipakka RA, Liao S. Modulation of obesity by a green tea catechin. Am J Clin Nutr. 2000;72(5):1232-1234.

[14] Rodriguez-Perez C, Segura-Carretero A, Del Mar Contreras M. Phenolic compounds as natural and multifunctional anti-obesity agents: a review. Crit Rev Food Sci Nutr. 2019;59(8):1212-1229.

[15] Akhlaghi M, Kohanmoo A. Mechanisms of Anti-Obesity Effects of Catechins: A Review. Int J Nutr Sci. 2018;3(3):127-132.

[16] Jurgens TM, Whelan AM, Killian L, Doucette S, Kirk S, Foy E. Green tea for weight loss and weight maintenance in overweight or obese adults. Cochrane Database Syst Rev. 2012;12:CD008650.

[17] Janssen I, Katzmarzyk PT, Ross R. Body mass index, waist circumference, and health risk: evidence in support of current National Institutes of Health guidelines. Archives of internal medicine. 2002;162(18):2074-2079.
[18] World Health Organization. Waist circumference and waisthip ratio: report of a WHO expert consultation Geneva, 8-11 December 2008. Geneva, Switzerland: Department of Nutrition for Health and Development, World Health Organization; 2011.

[19] Love J, Dropmann D, Selker R. Jamovi (Version 0.9). Jamovi. Amsterdam, Netherlands: Jamovi Project; 2018.

[20] Nabi BN, Sedighinejad A, Haghighi M, Farzi F, Rimaz S, Atrkarroushan Z, Biazar G. The anti-obesity effects of green tea: a controlled, randomized, clinical trial. Iranian Red Crescent Medical Journal. 2018;20(1).

[21] Wang H, Wen Y, Du Y, Yan X, Guo H, Rycroft JA, Boon N, Kovacs $E M$, Mela DJ. Effects of catechin enriched green tea on body composition. Obesity (Silver Spring). 2010;18(4):773-779.

[22] Prentice AM, Jebb SA. Beyond body mass index. Obesity reviews : an official journal of the International Association for the Study of Obesity. 2001;2(3):141-147.

[23] Brown AL, Lane J, Holyoak C, Nicol B, Mayes AE, Dadd T. Health effects of green tea catechins in overweight and obese men: a randomised controlled cross-over trial. $\mathrm{Br} J$ Nutr. 2011;106(12):1880-1889.

[24] Matsuyama T, Tanaka Y, Kamimaki I, Nagao T, Tokimitsu I. Catechin safely improved higher levels of fatness, blood pressure, and cholesterol in children. Obesity. 2008;16(6):13381348.

[25] Hursel R, Viechtbauer W, Westerterp-Plantenga MS. The effects of green tea on weight loss and weight maintenance: a meta-analysis. Int J Obes (Lond). 2009;33(9):956-961.

[26] Suliburska J, Bogdanski P, Szulinska M, Stepien M, PupekMusialik D, Jablecka A. Effects of green tea supplementation on elements, total antioxidants, lipids, and glucose values in the serum of obese patients. Biol Trace Elem Res. 2012;149(3):315-322.

[27] Sone T, Kuriyama S, Nakaya N, Hozawa A, Shimazu T, Nomura K, Rikimaru S, Tsuji I. Randomized controlled trial for an effect of catechin-enriched green tea consumption on adiponectin and cardiovascular disease risk factors. Food Nutr Res. 2011;55. 